\title{
Fostering Sustainable Development through Shifting Toward Rural Areas and Digitalization-The Case of Romanian Universities
}

\author{
Maria-Floriana Popescu ${ }^{1, *}$,, Bogdan-Cristian Chiripuci ${ }^{2, *}$, Andreea Orîndaru ${ }^{3}$, \\ Marius Constantin ${ }^{2}$ and Albert Scrieciu ${ }^{4}$ \\ 1 Faculty of International Business and Economics, The Bucharest University of Economic Studies, \\ 010374 Bucharest, Romania \\ 2 Faculty of Agri-Food and Environmental Economics, The Bucharest University of Economic Studies, \\ 010374 Bucharest, Romania; constantinmarius15@stud.ase.ro \\ 3 Faculty of Marketing, The Bucharest University of Economic Studies, 010374 Bucharest, Romania; \\ andreea.orindaru@mk.ase.ro \\ 4 National Institute of Marine Geology and Geoecology (GeoEcoMar), 024053 Bucharest, Romania; \\ albert.scrieciu@geoecomar.ro \\ * Correspondence: maria.popescu@rei.ase.ro (M.-F.P.); bogdan.chiripuci@gmail.com (B.-C.C.)
}

Received: 28 April 2020; Accepted: 11 May 2020; Published: 14 May 2020

\begin{abstract}
Educational institutions, especially universities, have been major pillars in societal transformation throughout society's history. They have been leading change through their discoveries, research results, and foremost, their example. Nowadays, universities have once again taken the role of leading change in a world that is profoundly determined to have a sustainable approach to life, paying attention to the long-term effects of their actions. In this sense, under the impact of deep digitalization, this paper advocates for the sustainable development of universities regarding campuses' expansion to rural areas. Moreover, it was demonstrated that sustainable development can be achieved by embracing the potential of digitalization. Based on a multicriteria analysis of the Romanian development regions, the research results showed that the rural area might be a welcoming environment for campuses of sustainable universities, based on digitalization at the level of the rural area in all activity fields, which is an initiative that would generate positive outcomes on many levels for different types of stakeholders, such as universities, students, staff, rural area population, and the nearby business environment. Future research aims to approach and explain the compounded effects of such an approach in depth and establish an even clearer picture of how beneficial such an expansion could prove to all factors considered under a knowledge-based society with digitized information as a vital pillar.
\end{abstract}

Keywords: university; sustainable development; sustainability; rural area

\section{Introduction}

Historically, higher education has been the starting point of transformation, discovery, and knowledge renewal and expansion. In the current fast-evolving society, higher education institutions are facing the challenge to continue leading the way toward a brighter future, where topics like sustainability and sustainable development are major pillars of every aspect of life. Taking this perspective into consideration, this study aimed to approach one possible way of turning universities into sustainable ones by expanding campuses toward rural areas, which is an approach that is likely to generate positive outcomes for multiple players, such as universities, students, teaching staff, rural populations, and the surrounding business environment [1]. In the long run, such an approach can 
have a ripple effect on every university's management team that can take these successful examples as an inspiration source for their expansion, and more importantly, for their awareness of possible solutions for becoming sustainable universities [2].

From a general perspective, education can be defined as a growing process where people gain a superior level of understanding and awareness of what is valuable or worth gaining in life, where happiness is only one purpose worth following in life [3]. Currently, people are increasingly more aware of the long-term impact of their actions, and as a result, society is constantly redefining happiness or life goals, moving toward more unity and interest in a long and nurturing life on this planet for this generation and future generations. Within this context, interest in sustainability and sustainable development is constantly growing.

Sustainability is defined as a way of meeting our own needs without compromising the ability of future generations to meet their own needs; it refers to natural resources, as well as social and economic resources, encompassing environmentalism, concerns for social equity, and economic development [4-7]. According to Ozasa [8], sustainability implies four major stages: from a sustainable construction industry, the creation of a sustainable built environment, toward sustainable communities, and ending up with global sustainability. The same author [8] points out that the university's role and impact cross all these levels of sustainability as a leader of change and innovation [9]. In other words, there is a new emerging function for universities and that is the co-creation of sustainability [10].

Universities are key hubs for innovation and environmental education within cities, thus they have the power to influence change to a more sustainable approach in every aspect of life [11]. However, there are still many higher education institutions that see sustainability as theoretical or disconnected from reality and fail to recognize the institutional benefits that may be brought about by pursuing sustainable development through university management [12]. Within this context, it is even more important to achieve awareness and act toward a sustainable institution to first gain a practical perspective of the concept, and second, to be an educational example for everyone around.

A sustainable university is defined as "a higher educational institution that addresses, involves and promotes, on a regional or a global level, the minimization of negative environmental, economic, societal, and health effects generated in the use of their resources in order to fulfil its functions of teaching, research, outreach and partnership, and stewardship in ways to help society make the transition to sustainable lifestyles" [11]. The Green Office Movement [13] defines a sustainable university as "an educational institution that educates global citizens for sustainable development, offers relevant insights on urgent societal challenges and reduces the environmental and social footprints of its campus operations, empowers students and staff to act, and makes sustainability a central priority." When focusing on a university's connections to sustainable community building, sustainability is "used colloquially to suggest the maintenance and survival of communities where it is recognized meaningful community engagement is essential for successful partnerships between post-compulsory education providers and the community to overcome barriers, raise aspirations and build community social and economic well-being" [14]. Additionally, the concept of campus sustainability motivates a strategy for the improvement of sustainable practices on campus to raise awareness among students and staff regarding sustainability and related issues [15].

Approaching sustainability in higher education management is discussed by Derrick [16] (pp. 47-63), who states that the higher education sector can take a longer-term perspective on sustainability than the business sector as it is not subject to market and short-term pressures in the same ways. Additionally, in terms of environmental impact, Sonetti, Lombardi, and Chelleri [11] show that educational functions account for $17 \%$ of the overall non-residential building stock in the EU, and since buildings are responsible for about $40 \%$ of the total final energy requirements in Europe, the educational sector accounts for $6.8 \%$ of the total EU energy consumption. To give an idea of the magnitude beyond the European case, the educational sector in China (which has 30 million students) accounts for $40 \%$ of the total energy consumption in public buildings, with $1.87 \mathrm{GJ} / \mathrm{m}^{2}$ of energy consumed in 2007 [11]. 
If we were to only consider this argument alone, it points out the importance of continuously supporting ambassadors of sustainable development integration in higher education [17]. While there are increasingly more indicators that higher education is moving toward a commitment to sustainability, there are also powerful societal forces at work against this progress [18]. This is why the combination of the knowledge on sustainability, the power to change, and interest in sustainability is what forms the three pillars for a sustainable transition [19].

The growing efforts toward building sustainable universities and campuses are reflected in the variety and increasing number of international associations and workgroups aimed at empowering universities to collaborate and share best practices for achieving increasingly more engagement toward their sustainability [20]. Such organizations include the International Sustainable Campus Network, The Association for the Advancement of Sustainability in Higher Education, Australasian Campuses Towards Sustainability, The Alliance for Global Sustainability, The Environmental Association for Universities and Colleges, Nordic Sustainable Campuses Network, Association of University Leaders for a Sustainable Future, and many others.

Moving on to rural areas and their specific features that can be valued through university campuses' expansion in those areas, Rinaldi and Cavicchi [10] argue that rural areas are characterized by interconnectedness, complicatedness, ambiguity, pluralism, and social constraints. Additionally, the developing countries face a major imbalance between rural and urban development, which leads to serious unsustainability [21]. In such an environment, the role of universities translates into regional economic development, with universities being a medium that can be used to promote a learning environment, develop skills, and build resources for competitiveness and social cohesion in rural areas [22]. The following advantages for developing rural-based universities or campuses were listed by Nkomo and Sehoole [23]: a) a strategic location within the rural community; b) existing and potential intellectual capital (with mission reorientation as a precondition, including the application of the appropriate development paradigm and enhancement of research); c) possesses the potential to promote the development of social capital; d) possesses the potential to promote appropriate and relevant teaching and learning methodologies; and e) possesses the potential to build strong collaborative relationships (partnerships) based on the "community of trust" notion (involving the university, community, business, government, etc.).

Regarding the promotion of digitalization in rural areas, the European Commission has developed and supports the project "A smart and sustainable digital future for European agriculture and rural areas," which aims to develop the current potential of digital technologies to help address economic and social challenges. Furthermore, a German initiative called "Smart Rural Areas," led by the Fraunhofer-Institute for Experimental Software Engineering (IESE) in Kaiserslautern, has proposed the "Smart City" model, which is a complex solution for rural development that includes, among others, the digitalization and development of education in these areas such that the level of migration to urban areas is reduced and causes new demographic changes to accelerate a trend among future residents in rural areas. At the same time, regarding gender distribution, the job vacancies that are proposed to be made available to the rural inhabitants do not target a specific gender category. This aspect welcomes young families for the development of new social communities in rural areas.

Given this background, the following sections describe the research approach proposed by the authors for discovering regions with high potential in terms of the openness and resource availability that are needed for a university expansion toward rural areas. As such, an argument for universities' expansion toward rural areas and its multiple benefits are further discussed.

\section{Materials and Methods}

To achieve a strategy for the development of universities that also includes the perspective offered by the rural world, we are putting forward the present case study, which is intended to provide, as accurately as possible, a framework of development possibilities and needs offered by each Romanian development region in terms of universities' expansion to rural areas, with everything that 
this implies. In this sense, based on the digitalization of the rural area, the entrepreneurs from the fields of activity within each development region can benefit from the scientific results of the university and research space, depending on the specifics of each area. In brief, our proposal involves the sustainable development of public-private partnerships in rural areas, which have a common starting point, namely digitalization. To design such a framework for universities' sustainable development toward rural areas, an assessment of Romania's potential, especially in rural areas, including human, natural, and financial resources, is needed. Additionally, aspects of digitalization were addressed in an econometric manner to extend the scope of sustainable development by turning toward rural areas [24-26].

In this sense, we decided to use the multicriteria analysis method, which the authors called the determination of the need for rural development. This is a method used for quantifying the economic transformation according to its parameters of expression (its behavior parameters), expressed through a series of clearly defined technical and economic indicators that are supported by qualitative information and data [27]. This type of quantification implies the following steps:

- Building the indicators' list, which can be used for analyzing the perspective of university development at the rural level for each development region.

- Assigning various importance coefficients to each indicator. The values of these coefficients must be between 5 and 10, depending on their influence on the potential of rural areas that universities can make practical and efficient use of (for 5-6, the degree of importance is considered to be secondary, $7-8$ is reported is considered of major importance, and 9-10 is considered of high importance).

- Establishing the rank for the 10 indicators at the level of each development region (setting the rank of each development region according to the reference regions; for the hierarchy, notes 1 to 8 are given in ascending order, including the development regions and the average of each indicator; this rank determination enabled us to also determine the criterion level priorities, which are needed in any analysis study).

- Calculating the aggregated note for each indicator according to Table A1 (Appendix A):

$$
\text { Nagik }=R k \times C
$$

where i represents the indicator (1-10) and $\mathrm{K}$ represents the region of development (N-E, S-E, S-V, V, N-V, S-M, Center, B-I).

- Determining the global indicator at the level of each development region. This step is based on the sum of aggregated notes found at the level of each development region:

$$
\mathrm{Ik}=\sum_{i=1}^{25} N a g i
$$

To identify the potential for university development in rural areas for each development region, the multicriteria analysis method was used at the regional level since each part of the country is characterized as having a different potential, and at the same time, there was a need to identify relatively homogeneous units. When applying this method, 10 indicators were used, which were seen as drivers of the potential for university development in the rural environment (Table 1).

All 10 indicators from Table 1 were assigned a value based on the importance given in terms of the potential of Romanian rural areas in all eight development regions. The lowest value was therefore attributed to the first indicator, "the traffic stress relief in major cities", as this is a secondary effect of universities' development toward the rural areas. When referring to the highest values for these indicators, we have included indicators such as "the creation of new specialist laboratories, campuses, canteens, and sports grounds"; "digitalization of the rural area"; and "the repopulation of villages and communes as a result of universities' development toward the rural area." This rank allocation was made to build the country's regions' rankings based on the need to extend the university framework 
to the rural area and the impact of such an expansion within those specific areas. The values of the indicators were given according to the importance of each one from the current perspective from the Romanian rural environment in terms of the current situation and in accordance with experts in the field [28-30]. In this sense, the values of the importance coefficients were reported, which aimed to follow the implementation of a possible feasibility study regarding the development of the rural environment. At the same time, an attempt was made to identify indicators such as "creation of new jobs in rural areas"; "use of the rural area's infrastructure for faculties focused on subjects like agriculture, veterinary, sport, and the military, in particular"; "creating the premises for accessing structural funds in rural areas as part of measures specific to non-agricultural activities"; "creating opportunities for entrepreneurship"; and "the creation of new specialized laboratories, campuses, canteens, and sports grounds" that could become goals for the development of the rural environment based on the digitalization process.

Table 1. The importance coefficients for the analyzed indicators.

\begin{tabular}{|c|c|c|}
\hline Item No. & Indicators & Coefficient of Importance \\
\hline 1 & Traffic stress relief in major cities & 6 \\
\hline 2 & Creation of new jobs in rural areas & 8 \\
\hline 3 & Developing social relationships within the rural community & 8 \\
\hline 4 & $\begin{array}{c}\text { Use of the rural area's infrastructure for faculties focused on } \\
\text { subjects like agriculture, veterinary, sport, and the military, in } \\
\text { particular }\end{array}$ & 9 \\
\hline 5 & $\begin{array}{l}\text { The creation of new specialized laboratories, campuses, } \\
\text { canteens, and sports grounds }\end{array}$ & 10 \\
\hline 6 & $\begin{array}{c}\text { The costs' reduction associated with purchasing or hiring } \\
\text { premises in urban areas }\end{array}$ & 8 \\
\hline 7 & $\begin{array}{l}\text { Creating the premises for accessing structural funds in rural } \\
\text { areas as a part of measures specific to non-agricultural activities }\end{array}$ & 8 \\
\hline 8 & Digitalization of the rural area & 10 \\
\hline 9 & Creating opportunities for entrepreneurship & 9 \\
\hline 10 & $\begin{array}{l}\text { The repopulation of villages and communes as a result of } \\
\text { universities' development toward the rural area }\end{array}$ & 10 \\
\hline
\end{tabular}

Furthermore, this research also aimed to quantify the impact that digitalization has had on the development of sustainable universities in Romania. To achieve this objective, a cross-sectional analysis was carried out, taking the year 2018 as a point of reference since this is the latest comprehensive statistical data available, but also taking into account that data were taken over from the databases of the Romanian National Institute of Statistics on 28 March 2020. The area covered is that of the 42 counties in Romania (41 plus Bucharest, which is the capital of Romania).

This method of cross-sectional linear regression is specific to a quantitative approach and belongs to the field of econometrics. The latter comprises techniques for analyzing the dynamics of variables in many fields of activity and the relationships between variables [31]. The cross-sectional linear regression is a form of regression that is meant to scientifically quantify and explain the link between the variables included in an econometric model. What is unique about this method is that the variables are associated with the same specific period in time (in this case, the year 2018) and the analysis is focused toward the subjects approached within the variables (in this case, the Romanian counties) rather than on how the values associated with the variables change over a long period [32].

\section{Results}

The global indicator was calculated as the sum of the aggregated notes obtained by each development region under the 10 indicators listed above. Depending on the value of each indicator's importance, the global indicator was determined, which led to discovering which Romanian rural area was most likely to generate higher results due to a university's expansion. 
As seen in Table 2, the lowest level of the global indicator was found in the Center region, which indicates that this region had the highest potential for university development toward rural areas. This area, which includes counties like Alba, Brasov, Covasna, Harghita, Mures, and Sibiu, is facing population migration to urban areas and other member states of the European Union. The development of this region may lead to the villages' increase in population as a result of the universities' expansion towards rural areas. This villages' increase in population will appear as a result of the creation of new specialized laboratories, campuses, canteens, and sports grounds, which will require various human resources (cleaning agents, medical staff, canteen staff, security guards, and so on). Besides auxiliary staff, new rural premises of universities will also require teaching staff, who according to the new trend at a national level, increasingly tend to choose to live in rural areas that are close to university-based cities. Therefore, by being employed in a rural area expansion of a university, the teaching staff can both satisfy their wish for living outside crowded cities and avoid a daily commute. Being a hilly and mountainous area, the Center region also offers a very pleasant recreation perspective for students who can enjoy relaxation, the clean air, and the favorable geographical position of their university center.

Table 2. Determination of the global indicator based on indicators I1-I10 (see Table 1).

\begin{tabular}{cccccccccccc}
\hline Region & I1 & I2 & I3 & I4 & I5 & I6 & I7 & I8 & I9 & I10 & TOTAL \\
\hline Bucharest-Ilfov & 6 & 48 & 6 & 48 & 6 & 6 & 6 & 48 & 48 & 48 & 270 \\
Center & 12 & 24 & 12 & 36 & 12 & 12 & 12 & 36 & 36 & 36 & 228 \\
North-East & 24 & 16 & 48 & 9 & 40 & 56 & 40 & 10 & 9 & 10 & 262 \\
South-West & 42 & 24 & 64 & 18 & 80 & 48 & 64 & 30 & 27 & 20 & 417 \\
South-East & 48 & 40 & 24 & 63 & 70 & 40 & 56 & 40 & 36 & 50 & 467 \\
South-Muntenia & 36 & 8 & 32 & 36 & 50 & 64 & 48 & 20 & 18 & 30 & 342 \\
South-West Oltenia & 30 & 48 & 56 & 45 & 60 & 32 & 32 & 50 & 45 & 40 & 438 \\
West & 18 & 56 & 40 & 27 & 30 & 24 & 24 & 70 & 63 & 70 & 422 \\
\hline
\end{tabular}

Source: Authors' conceptualization based on the multicriteria analysis method.

The Center region includes university centers in all six counties, as follows: there are two universities in Alba county, six universities in Brasov, five universities in Mures, three universities in Sibiu, two university centers in Covasna in the cities of Saint Gheorghe and Targu Secuiesc, and a center in Harghita in the town of Toplita. All these universities encompass several faculties with various subjects, depending on their specific characteristics, namely medical, sports, artistic, military, economic, legal, social, technological, linguistic, or religious subjects. The diversity of areas and the prospects offered by rural areas are an important argument for creating a business perspective, which can be developed in cooperation with each university, depending on their areas of interest. This would lead to the creation of new jobs, the development of rural turnover, and the development of social relationships within the rural community.

When referring to the analyzed global indicator, it can be seen that the Bucharest-Ilfov and North-East regions registered a score close to the Center region, which shows that these areas were also considered suitable for the development of the Romanian universities toward a rural area. The Bucharest-Ilfov region is the largest university center in Romania, with various universities (both public and private) encompassing all existing study areas. The great advantage of rural university facilities development in this area is the reduction of city traffic and expanding traffic to the areas outside the city where the population is growing, even though there is no infrastructure for this level of employment yet. At the same time, the North-East region encompasses a very important university center, namely the city of Iasi, which hosts high-profile faculties in the legal, medical, economic, technological, artistic, military, sports, and religious subjects. The development of university space in rural areas within this region would lead to the fluidity of traffic in Iasi, as well as the creation of new jobs and thus the context creation for repopulating the rural environment in counties such as Botosani, Suceava, Neamt, Bacau, and Vaslui. 
On the other side, the South-East region had the highest level of the global indicator, which shows that this area had limited potential for developing university space within Romanian rural areas. This area, comprising the counties of Braila, Buzau, Constanta, Galati, Tulcea, and Vrancea, registered a low university level. The universities from this region can be found in Constanta, with three universities; in Galati, with two universities; in Braila, with one university and some local branches of other universities; in Buzau, with one university and a remote territorial center of another university; in Vrancea, with various departments and remote territorial centers of three national universities; and in Tulcea, with only a remote territorial center of another university. The supply from the university perspective proves to be limited in terms of the diversity of subjects and numbers. Moreover, most of the university offerings in this region are based on low-frequency studies and not on daily university courses.

The areas' diversity and the rural areas' perspectives are the main issues that need to be taken into account when approaching a sustainable development strategy of the university premises. Nowadays, in the century of diversity and globalization, the expansion of university space should be a priority that, first of all, enables teaching staff to illustrate and manifest their pedagogical art. Moreover, the analyzed indicators provide important considerations regarding the expansion of university space to Romanian rural areas.

Society has significantly changed due to the impact technology has had on the activities that people engage in daily. In the era of digital transformation, information is much more fluid and is changing business aspects, while new challenges and opportunities have emerged [33]. It is no longer a question of whether developing sustainably via digitalization is desirable, but it is slowly becoming a requirement in a society where information is only a few clicks or taps away from a user of intelligent devices that are connected to the Internet. The link between digitalization and sustainability is strong in knowledge-based societies, where digitalization plays a very important role in education and ensures sustainable development, based on all the benefits involved, such as digital tools that develop and increase the competences of the population; quick communication and file transfer; and eliminating limitations, such as location when communicating [34].

Sustainability through digitalization is quickly becoming a matter of interest in Romania, including in rural areas. In the context of a sustainable university's development toward a rural area in Romania, digitalization plays a key role that can ease this transition in a balanced manner.

The cross-sectional linear regression methodology was applied in this research using the least-squares method. The designed model provides ways to determine the existence or nonexistence of correlations between two types of variables: a dependent variable, which is also called an endogenous variable, and the independent variable, which is also called an exogenous variable [35]. The simple linear regression methodology was applied to the cross-sectional data (for further information, see Table A2 in Appendix B), which is characterized by the observations made at a particular moment, namely the year 2018, of several entities (the 42 Romanian counties), referring to a single phenomenon (digitalization's impact on a sustainable university's development).

The variables included in the cross-sectional analysis were the following:

- SCL112C-“PCs in the school and university unit administration". This indicator is defined by the Romanian National Institute of Statistics as the number of "personal computers with hardware, monitor and keyboard used in school units administration". For this research, out of the total number of computers, the ones under the administration of universities were deducted since the purpose was to quantify the influence digitalization has on a university's sustainable development. It would not be relevant to consider the university's assets because the beneficiaries of the computers would be members of the universities, and therefore, this does not have any impact on the development of universities.

- SCL101E- "Faculties" Data was collected at the beginning of the school year (academic year) in educational units. This indicator represents the total number of existing faculties in each of the 42 Romanian counties. 
The endogenous (dependent) variable was SCL101E_-"Faculties" and the exogenous (independent, explanatory) variable was SCL112C - "PCs in the school and university unit administration" (Table 3). As stated before, digitalization is part of education and ensures sustainable development, including the case of universities. This cross-sectional analysis aimed to highlight how digitalization (represented by the use of computers in the undergraduate educational institutions) influenced the development of universities in each Romanian county.

Table 3. The results of the cross-sectional regression (least-squares method).

\begin{tabular}{ccccc}
\hline Variable & Coefficient & Standard Error & $t$-Statistic & Prob. \\
\hline C & -28.72470 & 3.533415 & -8.129445 & 0.0000 \\
SCL112C & 0.006147 & 0.000456 & 13.47495 & 0.0000 \\
\hline $\mathrm{R}^{2}$ & 0.819474 & Mean dependent var & 12.97619 \\
Adjusted R & 0.814960 & S.D. dependent var & 25.69093 \\
S.E. of regression & 11.05127 & Akaike info criterion & 7.689415 \\
Sum of the squared residuals & 4885.220 & Schwarz criterion & 7.772161 \\
Log likelihood & -159.477 & Hannan-Quinn criterion & 7.719745 \\
F-statistic & 181.5743 & Durbin-Watson stat & 1.948194 \\
Prob(F-statistic) & \multicolumn{3}{c}{0.000000} \\
\hline
\end{tabular}

Source: Author's conceptualization (data extracted from the Romanian National Institute of Statistics, processed in EViews 10 Student Version Lite (IHS Global Inc., Irvine, CA, USA).

The coefficient of determination indicated that the cross-sectional linear equation successfully predicted $(81.94 \%)$ the values of the dependent variable. In Romania, in 2018, the number of faculties was explained by the exogenous variable (the number of computers, each with hardware, a monitor, and a keyboard, used in educational institutions) with a proportion of $81.94 \%$. The Durbin-Watson statistic measured the serial correlation in the residuals and suggested that successive error terms were positively correlated, taking into account the value, which was slightly below 2 (1.96). This value validates the cross-sectional regression model [36].

According to Table 4, should the undergraduate educational institutions from any Romanian county have 5000 computers, each with hardware, a monitor, and a keyboard available, then it was $81.94 \%$ likely that the respective county had two faculties that are providing higher education services. The mean value of SCL112C was 6784.381 with a standard deviation of 3783.661. In 2018, the maximum values were registered in Bucharest, where there were 25,138 computers available in the undergraduate educational institution and 158 active faculties. On the other hand, the minimum values were registered in Giurgiu, a county where there were no faculties and only 2189 computers available in the undergraduate educational institutions. This statistical evidence was strongly correlated with the fact that the rural areas in Romania imposed specific targeted strategies for counties to obtain sustainable development [37], including via education digitalization.

Furthermore, based on the data from Table 4 , the confidence intervals for variables included in the cross-sectional linear regression confirmd that in the case of lower bounds:

- With a $90 \%$ confidence rate, should the undergraduate educational institutions from any Romanian county have 6000 computers, each with hardware, a monitor, and a keyboard available, then the respective county has three faculties that are providing higher education services $(6000 \times 0.005379$ -34.6744 , which is 2.9786 faculties).

- With a $95 \%$ confidence rate, should the undergraduate educational institutions from any Romanian county have 7000 computers, each with hardware, a monitor, and a keyboard available, then the respective county is likely to have one faculty that is providing higher education services $(7000 \times$ $0.005225-35.8660$, which is 0.709 ).

- With a $100 \%$ confidence rate, should the undergraduate educational institutions from any Romanian county have 8000 computers, each with hardware, a monitor, and a keyboard available, 
then the respective county has one faculty that is providing higher education services to the local community $(8000 \times 0.004913-38.2806$, which is 1.0234$)$.

Additionally, based on the data from Table 4, in the case of the upper bounds with a $100 \%$ confidence rate, should the undergraduate educational institutions from any Romanian county have 3000 computers, each with hardware, a monitor, and a keyboard available, then the respective county has three faculties that are providing higher education services to the local community $(3000 \times 0.007380$ - 19.1687, which represents 2.9713 faculties).

Table 4. The estimation command, equation, and substituted coefficients. Confidence intervals.

\begin{tabular}{|c|c|c|c|c|c|c|c|}
\hline \multicolumn{8}{|c|}{ Estimation Command: } \\
\hline \multicolumn{8}{|c|}{ LS SCL101E C SCL112C } \\
\hline \multicolumn{8}{|c|}{ Estimation Equation: } \\
\hline \multicolumn{8}{|c|}{$\mathrm{SCL101E}=\mathrm{C}(1)+\mathrm{C}(2) \times \mathrm{SCL112C}+\varepsilon$} \\
\hline \multicolumn{8}{|c|}{ Substituted Coefficients: } \\
\hline \multicolumn{8}{|c|}{ SCL101E $=-28.72470+0.006147 \times$ SCL112C $+\varepsilon$} \\
\hline & & \multicolumn{2}{|c|}{$90 \% \mathrm{CI}$} & \multicolumn{2}{|c|}{$95 \% \mathrm{CI}$} & \multicolumn{2}{|c|}{$100 \% \mathrm{CI}$} \\
\hline Variable & Coefficient & Low & High & Low & High & Low & High \\
\hline $\mathrm{C}$ & -28.7247 & -34.6744 & -22.7749 & -35.8660 & -21.5834 & -38.2806 & -19.1687 \\
\hline INT104C/D & 0.006147 & 0.005379 & 0.006915 & 0.005225 & 0.007069 & 0.004913 & 0.007380 \\
\hline
\end{tabular}

Source: Author's conceptualization (data extracted from the Romanian National Institute of Statistics, processed in EViews 10 Student Version Lite.

According to Figure 1, the following counties had trouble fitting properly into the cross-sectional regression model: Bacau, Suceava, Arges, Prahova, and Bucharest. This was due to the high number of faculties existing in some counties, relative to the national average (Bucharest: 158 faculties relative to a mean of approximately thirteen faculties, which represents twelve times the mean; however, it should be considered that Bucharest is the capital of Romania and attracts a lot of students due to the quality provided in the higher education system). On the other hand, Suceava had ten active faculties reported in 2018, three faculties below the national average of thirteen and with 3473 more computers available in the undergraduate educational institutions relative to the national average of 6784 . These deviations from the mean caused abnormalities when analyzing the residuals of the model.

According to Figure 2, the residual distribution was normal, taking into account the fact that the residual mean was zero. There was a very small tendency toward a negative asymmetry (the skewness value was slightly below the ideal zero threshold), but we consider it acceptable. The kurtosis value (4.66) indicated a leptokurtic distribution of the residuals, which is not considered a normal distribution (the value of a normal distribution is 3). This was also confirmed by the Jarque-Bera value, with an ideal value situated around zero in the case of a normal distribution [37]. The leptokurtic distribution of the residuals was caused by 31 counties ( $73.8 \%$ of the total) that had 12 or fewer active faculties in 2018. This highlighted that the most developed counties in Romania were deeply digitized and that the effects of investing in digitalization were visible and took the form of a thirst for knowledge. Moreover, the latter took the shape of a demand for sustainable higher education. 


County
Bihor
Bistrita-Nasaud
Cluj
Maramures
Satu Mare
Salaj
Alba
Brasov
Covasna
Harghita
Mures
Sibiu
Bacau
Botosani
Iasi
Neamt
Suceava
Vaslui
Braila
Buzau
Constanta
Galati
Tulcea
Vrancea
Arges
Calarasi
Dambovita
Giurgiu
Ialomita
Prahova
Teleorman
Ilfov
Municipiul Bucuresti
Dolj
Gorj
Mehedinti
Olt
Valcea
Arad
Caras-Severin
Hunedoara
Timis

$\begin{array}{rrr}\text { Actual } & \text { Fitted } & \text { Residual } \\ 22 & 22.4519 & -0.4519 \\ 3 & -0.6101 & 3.6101 \\ 49 & 44.4076 & 45.924 \\ 7 & 15.2419 & 8.2419 \\ 5 & 3.1024 & 1.8975 \\ 4 & 4.1321 & 8.1321 \\ 8 & 8.3208 & -0.3208 \\ 22 & 14.5966 & 7.4034 \\ 2 & -8.6130 & 10.6130 \\ 3 & 8.6466 & -5.6466 \\ 16 & 19.5814 & -3.5814 \\ 12 & 10.8779 & 1.1221 \\ 6 & 26.4472 & -20.4472 \\ 0 & 4.8603 & -4.8603 \\ 43 & 41.5740 & 1.4260 \\ 4 & 17.3994 & -13.3994 \\ 10 & 34.3210 & -24.3210 \\ 0 & 6.7842 & -6.7842 \\ 2 & -3.1240 & 5.1241 \\ 3 & 12.9431 & -9.9431 \\ 25 & 32.6061 & -7.6061 \\ 16 & 15.0268 & 0.9731 \\ 0 & -7.4082 & 7.4082 \\ 2 & 0.4040 & 1.5959 \\ 11 & 27.4368 & -16.4368 \\ 1 & -5.7609 & 6.7609 \\ 10 & 13.0230 & -3.023 \\ 0 & -15.2698 & 15.2698 \\ 0 & -7.2607 & 7.2607 \\ 5 & 34.8742 & -29.8742 \\ 3 & -3.4744 & 6.4744 \\ 1 & -4.6177 & 5.6177 \\ 158 & 12.5789 & 32.2114 \\ 17 & 21.5053 & -4.5053 \\ 4 & 2.8995 & 1.1004 \\ 5 & -7.7586 & 12.7586 \\ 2 & 2.6598 & -0.6598 \\ 3 & 0.4532 & 2.5467 \\ 16 & 9.6792 & 6.3207 \\ 3 & -6.0929 & 9.0929 \\ 4 & 9.4764 & -5.4764 \\ 38 & 31.7333 & 6.2667\end{array}$

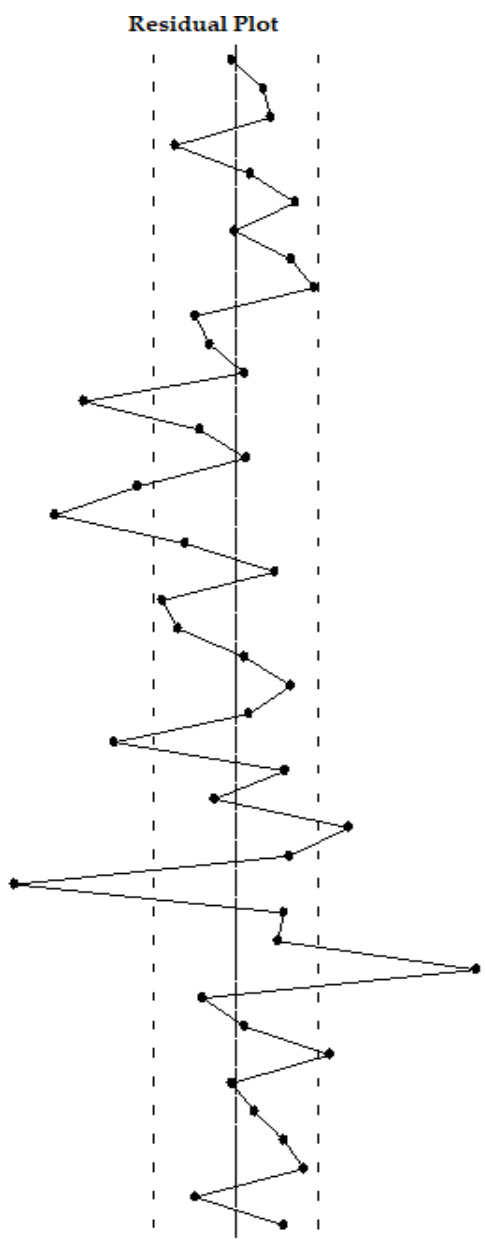

Figure 1. Residual plot with the observations, along with actual and fitted residuals. Source: Author's conceptualization (data extracted from the Romanian National Institute of Statistics, processed in EViews 10 Student Version Lite).

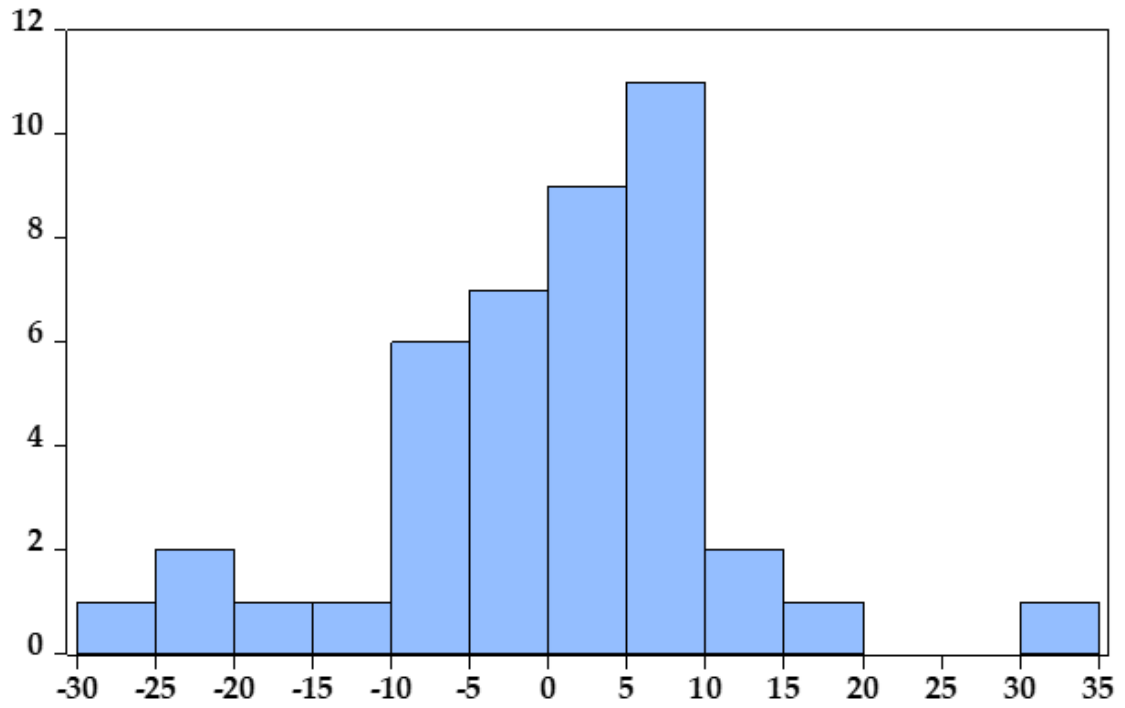

Series: Residuals

Observations: 42

Mean 0

Median

Maximum

Minimum

$-29.8741$

Std. Dev.

10.9156

Skewness

Kurtosis

4.6616

Jarque-Bera

5.4035

Probability

0.0670

Figure 2. Residual histogram. Source: Author's conceptualization (data extracted from the Romanian National Institute of Statistics, processed in EViews 10 Student Version Lite). 


\section{Discussion}

The model developed in this study validated the fact that the distribution of faculties among counties in Romania in 2018 was strongly correlated to the degree of digitalization in each county, considering the values of the indicators previously analyzed, which were specific to the cross-sectional linear regression method used [36]. Bucharest and other highly digitized counties—such as Cluj, Iasi, and Timis—represent reference points for other less digitized counties with growth potential—such as Ilfov, Giurgiu, and Ialomita-where investments are necessary to ensure sustainable development through digitalization.

Therefore, digitalization had a strong influence on sustainable university development in Romania, as demonstrated in the quantitative analysis. Digitalization represents a thirst for knowledge in the knowledge-based society and creates demand for higher education, which is provided in a sustainable manner by universities. Shifting the focus toward universities in the rural areas contributes toward reaching the goal of sustainable development and it should be considered in accordance with the latent potential of digitalization in the rural areas of Romania when pursuing sustainability.

In today's knowledge-based society, the application of sustainable development principles has a well-defined role at the university level and students' responsiveness in this respect is high. Ensuring a clean environment, reducing pollution, reducing consumerism, having an active involvement in the well-being of society, and encouraging socially responsible consumption are objectives that any university should have, regardless of their specific characteristics. Moreover, each faculty should find ways to contribute more profoundly to the objectives set out above, according to its specific characteristics. To this end, rural areas offer a unique opportunity for practical examples. Therefore, there are two important aspects, namely the students' responsiveness and the university's subject diversity; these two together can become the first pillar of the foundation for building a sustainable university in a rural and urban-rural society. Naturally, with the growth of several generations of well-trained students willing to achieve social sustainability, their involvement in any field of activity will become an example for those around them.

The limits of our research are the limited case taken into consideration (Romania), without having a wider perspective, and the fact that it is short on explaining the downsides of a university's expansion toward rural areas for the different actors involved. Moreover, the topic of achieving the goal of sustainable development of universities through digitalization was mainly approached from the perspective of technology and how it ultimately produced sustainable development. However, technology and digitalization focus on another vector as well, which is essential for amplifying the effects of the latter on the sustainable development of universities. This vector is mankind. Consequently, another limitation of this research refers to the impact humans have on digitalization and how it can be used as a vehicle for change toward sustainable development. Additionally, future research directions should investigate these issues and find a more general indicator of university's expansion outcomes that can be used in any context and reduces the subjective influence of the researcher. Moreover, testing the real-life effects of such an expansion in a university that has chosen to expand toward a rural area might offer a much deeper understanding of the entire expansion perspective.

\section{Conclusions}

This paper emphasized the importance of digitalization, which a tremendous potential to foster sustainable development through the creation of a healthy socio-economic and educational environment. It has helped connect, enable communication, and empower people by bringing them together rather than just talking about rural or urban areas, men or women. With all of this, our growth environment has been shaped by its diverse features and pillars.

As far as the current research is concerned, its purpose was to demonstrate the usefulness of developing the university space toward the Romanian rural areas, and at the same time, to use this perspective as a premise for creating new jobs that would naturally allow for the development of the social relationship within the rural community. Additionally, rural entrepreneurship could have new horizons, with different collaboration prospects with sustainable universities, depending on the study 
field of each faculty. Furthermore, there are several advantages from the financial perspective of the institution management since the costs in rural areas are much lower and the provision of facilities specific to the needs of individual faculties can be achieved by accessing the national Sustainable Development Program 2014-2020 measures that are specific to non-agricultural activities. Different operational programs can be used to achieve these goals but the amounts allocated are much lower.

As the demographic factors define the quality of life in rural areas, while at the same time affecting economic growth, social development, and quality of life, further indicators should be used in future studies in this field, such as intersectionality theory, which asserts that individuals are often disadvantaged by multiple sources of oppression: race, class, gender identity, sexual orientation, religion, and other markers of identity, and could reveal important differences and conclusions that could enhance and broaden the knowledge in this field.

In conclusion, this research is a starting point for the development of the university space toward Romanian rural areas, which is a premise for new growth directions that can be adapted to each faculties' special features. At the same time, each part of Romania is different and thus the approach of such an expansion of university campuses toward rural areas should be made according to each area's potential, especially when referring to each area's business potential. Digitalization facilitates the transition toward sustainable development and it is no longer a matter of whether it will reshape and enhance the knowledge transfer process in universities (not limited to those), but a matter of when it will be completely integrated with the needs, demands, and particularities of universities, especially those in rural and less developed areas.

Author Contributions: Conceptualization, M.-F.P., B.-C.C., A.O., M.C. and A.S.; Methodology, B.-C.C., M.C. and A.S.; Software, B.-C.C. and M.C.; Validation, M.-F.P., B.-C.C. and A.O.; Formal Analysis, M.-F.P., A.O. and A.S.; Investigation, B.-C.C. and M.C.; Resources, M.-F.P., B.-C.C., A.O., M.C. and A.S.; Data Curation, B.-C.C., M.C. and A.S.; Writing-Original Draft Preparation, M.-F.P, B.-C.C., A.O., M.C. and A.S.; Writing-Review \& Editing, M.-F.P., B.-C.C., A.O. and M.C.; Visualization, B.-C.C. and M.C.; Supervision, M.-F.P. and B.-C.C.; Project Administration, M.-F.P. and B.-C.C.; Funding Acquisition, A.S. All authors have read and agreed to the published version of the manuscript.

Funding: The research leading to these results has been supported by the Romanian Ministry of Research and Innovation, through the Core Program (Program Nucleu) - "Developing integrated management for the pilot areas of the Romanian Danube sector, influenced by climate change and anthropic interventions, by applying complex research methodologies," contract no. 13N/08.02.2019, carried out by National Institute for Research and Development of Marine Geology and Geoecology GeoEcoMar. The financial support for this paper was provided by the Romanian Ministry of Research and Innovation, through Programme 1-Development of the National System of Research-Institutional Performance, Project of Excellence in Research-Innovation, contract no. 8PFE/2018.

Conflicts of Interest: The authors declare no conflict of interest. The sponsors had no role in the design, execution, interpretation, or writing of the study.

\section{Appendix A}

Table A1. Calculation of the aggregated notes.

\begin{tabular}{|c|c|c|c|c|c|c|c|c|c|c|c|}
\hline $\begin{array}{l}\text { The Indicator } \\
\text { Region }\end{array}$ & I1 & I2 & I3 & I4 & I5 & I6 & I7 & I8 & I9 & I10 & TOTAL \\
\hline Indicator's rank & 6 & 8 & 8 & 9 & 10 & 8 & 8 & 10 & 9 & 10 & - \\
\hline Bucharest-Ilfov & 3 & 7 & 5 & 3 & 3 & 3 & 3 & 7 & 7 & 7 & 48 \\
\hline Center & 1 & 8 & 1 & 8 & 1 & 1 & 1 & 8 & 8 & 8 & 45 \\
\hline North-East & 2 & 4 & 2 & 6 & 2 & 2 & 2 & 6 & 6 & 6 & 38 \\
\hline South-West & 4 & 2 & 6 & 1 & 4 & 7 & 5 & 1 & 1 & 1 & 32 \\
\hline South-East & 7 & 3 & 8 & 2 & 8 & 6 & 8 & 3 & 3 & 2 & 50 \\
\hline South-Muntenia & 8 & 5 & 3 & 7 & 7 & 5 & 7 & 4 & 4 & 5 & 55 \\
\hline South-West Oltenia & 6 & 1 & 4 & 4 & 5 & 8 & 6 & 2 & 2 & 3 & 41 \\
\hline West & 5 & 6 & 7 & 5 & 6 & 4 & 4 & 5 & 5 & 4 & 51 \\
\hline
\end{tabular}

Source: Authors' conceptualization, based on the multicriteria analysis method. 


\section{Appendix B}

Table A2. Values of the indicators used in the cross-sectional regression (Romania, 2018).

\begin{tabular}{|c|c|c|}
\hline \multirow{2}{*}{ County Name } & \multicolumn{2}{|c|}{ Indicator Code } \\
\hline & SCL101E & SCL112C \\
\hline Bihor & 22 & 8326 \\
\hline Bistrita-Nasaud & 3 & 4574 \\
\hline Cluj & 49 & 11,898 \\
\hline Maramures & 7 & 7153 \\
\hline Satu Mare & 5 & 5178 \\
\hline Salaj & 4 & 4001 \\
\hline Alba & 8 & 6027 \\
\hline Brasov & 22 & 7048 \\
\hline Covasna & 2 & 3272 \\
\hline Harghita & 3 & 6080 \\
\hline Mures & 16 & 7859 \\
\hline Sibiu & 12 & 6443 \\
\hline Bacau & 6 & 8976 \\
\hline Botosani & 0 & 5464 \\
\hline Iasi & 43 & 11,437 \\
\hline Neamt & 4 & 7504 \\
\hline Suceava & 10 & 10,257 \\
\hline Vaslui & 0 & 5777 \\
\hline Braila & 2 & 4165 \\
\hline Buzau & 3 & 6779 \\
\hline Constanta & 25 & 9978 \\
\hline Galati & 16 & 7118 \\
\hline Tulcea & 0 & 3468 \\
\hline Vrancea & 2 & 4739 \\
\hline Arges & 11 & 9137 \\
\hline Calarasi & 1 & 3736 \\
\hline Dambovita & 10 & 6792 \\
\hline Giurgiu & 0 & 2189 \\
\hline Ialomita & 0 & 3492 \\
\hline Prahova & 5 & 10,347 \\
\hline Teleorman & 3 & 4108 \\
\hline Ilfov & 1 & 3922 \\
\hline Municipiul Bucuresti & 158 & 25,138 \\
\hline Dolj & 17 & 8172 \\
\hline Gorj & 4 & 5145 \\
\hline Mehedinti & 5 & 3411 \\
\hline Olt & 2 & 5106 \\
\hline Valcea & 3 & 4747 \\
\hline Arad & 16 & 6248 \\
\hline Caras-Severin & 3 & 3682 \\
\hline Hunedoara & 4 & 6215 \\
\hline Timis & 38 & 9836 \\
\hline
\end{tabular}

Source: Own conceptualization, data extracted from the Romanian National Institute of Statistics.

\section{References}

1. Albiez, M.; Banse, G.; Kenyon, L.; Quint, A. Designing Sustainable Urban Futures: Concepts and Practices from Different Countries; KIT Scientific Publishing: Karlsruhe, Germany, 2016.

2. Filho, W.L.; Salvia, A.L.; Pretorius, R.W.; Brandli, L.L.; Manolas, E.; Alves, F.; Azeiteiro, U.; Rogers, J.; Shiel, C.; Paco, A.D. Universities as Living Labs for Sustainable Development: Supporting the Implementation of the Sustainable Development Goals; Springer: Cham, Switzerland, 2019. 
3. Gibbs, P. Happiness and education: Troubling students for their own contentment. Time Soc. 2015, 24, 54-70. [CrossRef]

4. UN World Commission on Environment and Development. Report of the World Commission on Environment and Development: Our Common Future; Oxford University Press: Oxford, UK, 1987.

5. United Nations General Assembly. Resolution Adopted by the General Assembly; UNGA: New York, NY, USA, 2005.

6. Vogt, K.A.; Patel-Weynand, T.; Shelton, M.; Gordon, J.C.; Vogt, D.J.; Mukumoto, C.; Suntana, A.S.; Roads, P.A. Sustainability Unpacked: Food, Energy and Water for Resilient Environments and Societies; Earthscan from Routledge: New York, NY, USA, 2010.

7. Osburg, T. Sustainability in a Digital World Needs Trust. In Sustainability in a Digital World: New Opportunities Through New Technologies; Osburg, T., Lohrmann, C., Eds.; CSR, Sustainability, Ethics \& Governance; Springer International Publishing: Cham, Switzerland, 2017; pp. 3-19.

8. Ozasa, T. How to Create Sustainable Campus Assessment System; Hokkaido University: Sapporo, Japan, 2015.

9. Lohrmann, C. Leadership in a Digital World: New Ways of Leadership for Sustainable Development. In Sustainability in a Digital World: New Opportunities Through New Technologies; Osburg, T., Lohrmann, C., Eds.; CSR, Sustainability, Ethics \& Governance; Springer International Publishing: Cham, Switzerland, 2017; pp. 51-58.

10. Rinaldi, C.; Cavicchi, A. Universities' Emerging Missions to Foster Sustainability of Rural Areas: Multiple Case Studies From The Marche Region. Agric. Agric. Sci. Procedia 2016, 8, 725-731. [CrossRef]

11. Sonetti, G.; Lombardi, P.; Chelleri, L. True Green and Sustainable University Campuses? Toward a Clusters Approach. Sustainability 2016, 8, 83. [CrossRef]

12. Leal Filho, W. Sustainability and University Life. Int. J. Sustain. High. Educ. 2000, 1. [CrossRef]

13. Green Office Movement. What is a Sustainable University? Green Office Movement: Copenhagen, Denmark, 2019.

14. Roberts, P.; Downes, N. Conflicting messages: Sustainability and education for rural-regional sustainability. Rural Soc. 2016, 25, 15-36. [CrossRef]

15. Er, A.C.; Karudan, R. Promoting Campus Sustainability: A Conceptual Framework for the Assessment of Campus Sustainability. e-Bangi 2018, 13, 36-63.

16. Sustainability Assessment Tools in Higher Education Institutions: Mapping Trends and Good Practices Around the World; Caeiro, S.; Filho, W.L.; Jabbour, C.; Azeiteiro, U.M. (Eds.) Springer International Publishing: Cham, Switzerland, 2013.

17. Verhulst, E.; Lambrechts, W. Fostering the incorporation of sustainable development in higher education. Lessons learned from a change management perspective. J. Clean. Prod. 2015, 106, 189-204. [CrossRef]

18. Calder, W.; Clugston, R.M. Progress toward Sustainability in Higher Education. Envtl. L. Rep. News Anal. 2003, 33, 10003.

19. Csurgó, B.; Kovách, I.; Kučerová, E. Knowledge, Power and Sustainability in Contemporary Rural Europe. Sociol. Rural. 2008, 48, 292-312. [CrossRef]

20. Filho, W.L. Sustainability at Universities-Opportunities, Challenges and Trends; Peter Lang Scientific Publishers: Frankfurt, Germany, 2009.

21. Ji, X.; Ren, J.; Ulgiati, S. Towards urban-rural sustainable cooperation: Models and policy implication. J. Clean. Prod. 2019, 213, 892-898. [CrossRef]

22. Boucher, G.; Conway, C.; Van Der Meer, E. Tiers of Engagement by Universities in their Region's Development. Reg. Stud. 2003, 37, 887-897. [CrossRef]

23. Nkomo, M.; Sehoole, C. Rural-based universities in South Africa: Albatrosses or potential nodes for sustainable development? Int. J. Sustain. High. Educ. 2007, 8, 234-246. [CrossRef]

24. Aksin-Sivrikaya, S.; Bhattacharya, C.B. Where Digitalization Meets Sustainability: Opportunities and Challenges. In Sustainability in a Digital World: New Opportunities Through New Technologies; Osburg, T., Lohrmann, C., Eds.; CSR, Sustainability, Ethics \& Governance; Springer International Publishing: Cham, Switzerland, 2017; pp. 37-49.

25. Gensch, C.-O.; Prakash, S.; Hilbert, I. Is Digitalisation a Driver for Sustainability. In Sustainability in a Digital World: New Opportunities Through New Technologies; Osburg, T., Lohrmann, C., Eds.; CSR, Sustainability, Ethics \& Governance; Springer International Publishing: Cham, Switzerland, 2017; pp. 117-129.

26. Selwyn, N. Digital Technology and the Contemporary University: Degrees of Digitization; Routledge: New York, NY, USA, 2014. 
27. Aprodu, C.I. Decalajele Agricole și Dezvoltarea Economică Regională în România; Academia de Studii Economice din București: Bucharest, Romania, 2006.

28. Bălan, M. Particularities Of The Youth Labour Market In Romanian Rural Areas. Sci. Pap. Ser. Manag. Econ. Eng. Agric. Rural Dev. 2019, 19, 63-70.

29. Diaconeasa, M.C.; Chirculescu, R.E. The Level of Employability in the Romanian Rural Area. In Proceedings of the International Conference on Competitiveness of Agro-food and Environmental Economy Proceedings, Bucharest, Romania, 10-11 November 2016; Volume 5, pp. 133-140.

30. Mărăcineanu, F.; Constantin, E.; Luca, E.; Manea, R. Strategia demografică în România. Agricultura $2009,71$. [CrossRef]

31. Anghelache, C.; Petre, A.; Olteanu, C. Some Concepts and Econometric Models of Macroeconomic Performance Analysis. Rom. Stat. Rev. Suppl. 2019, 4, 3-20.

32. Krueger, D.; Perri, F.; Pistaferri, L.; Violante, G.L. Cross-sectional facts for macroeconomists. Rev. Econ. Dyn. 2010, 13, 1-14. [CrossRef]

33. Jovanović, M.; Dlačić, J.; Okanović, M. Digitalization and society's sustainable development-Measures and implications. Zb. Rad. Ekon. Fak. Rij. 2018, 36, 24.

34. Görgényi-Hegyes, É; Csapó, I.; Fekete-Farkas, M. Some aspects of digitalization and sustainability in the European Union. Vadyba 2017, 31,37-46.

35. Gheorghiță, M.; Pătărlăgeanu, S.R. Econometrie; Editura ASE: Bucharest, Romania, 2006.

36. Startz, R. EViews Illustrated; University of California: Santa Barbara, CA, USA, 2019.

37. Pătărlăgeanu, S.R.; Negrei, C.; Dinu, M.; Chiocaru, R. Reducing the Carbon Footprint of the Bucharest University of Economic Studies through Green Facades in an Economically Efficient Manner. Sustainability $2020,12,3779$.

(C) 2020 by the authors. Licensee MDPI, Basel, Switzerland. This article is an open access article distributed under the terms and conditions of the Creative Commons Attribution (CC BY) license (http://creativecommons.org/licenses/by/4.0/). 